\title{
PENGARUH SERVICE QUALITY, CUSTOMER SATISFACTION, DAN BRAND TRUST DI MEDIASI OLEH CUSTOMER COMMITMENT TERHADAP CUSTOMER LOYALTY PENUMPANG MASKAPAI LOW COST CARRIER DI BALI
}

\author{
Dewa Ayu Alit Lakhsmidevy ${ }^{1, a)}$, Mochammad Rizan ${ }^{2, b)}$, dan Ari Warokka ${ }^{3, c)}$ \\ 1,2,3 Program Studi Magister Management Universitas Negeri jakarta , \\ Jl. Raya Rawamangun Muka Kampus A UNJ,Rawamangun - Jakarta Timur, Indonesia, 13220
}

a)Dewayu.all@gmail.com, b) dr_rizan@yahoo.com, ${ }^{\text {c) }}$ ari.warokka@gmail.com

\begin{abstract}
Abstrak
Kebutuhan masyarakat Indonesia atas layanan transportasi terus meningkat sesuai dengan meningkatnya pembangunan nasional. Jenis layanan transportasi udara juga terus berkembang, salah satu adalah dengan beroperasinya model penerbangan unik yaitu melalui strategi penurunan operating cost di semua lini yang mengakibatkan harga tiket dapat ditekan. Model penerbangan ini disebut low cost carrier (LCC). Kepuasan konsumen terhadap pelayanan yang diberikan oleh maskapai penerbangan di Indonesia sangat berpengaruh terhadap seberapa besar tingkat kualitas pelayanan dari sebuah maskapai penerbangan. Berbagai pelayanan yang mempengaruhi, kepuasan konsumen adalah keramahan seluruh awak kabin, fasilitas fisik yang ada, tarif penerbangan, ketepatan waktu keberangkatan kemudahan akses dan juga keselamatan penerbangan. Berdasarkan jajak pendapat dari 2.674 orang responden mengenai apa yang diinginkan dari sebuah maskapai penerbangan didapatkan hasil sebanyak 9,6\% menginginkan pelayanan ramah dari awak kabin, $16,9 \%$ penerbangan yang tepat waktu, armada yang baru 18,3\%, 55,2\% tarif yang murah (Indopos. 2015). Maskapai penerbangan di Indonesia sering mengalami keterlambatan waktu pada saat akan terbang atau dengan kata lain sering mengalami delay. Salah satu maskapai penerbangan di Indonesia yang sering mengalami keterlambatan dalam pemberangkatan pesawat adalah penerbangan low cost carriers. Secara garis besar tujuan penelitian ini adalah : menguji pengaruh service quality, customer satisfaction, brand trust terhadap costumer commitment serta dampaknya kepada customer loyalty pada penerbangan domestik maskapai low cost carrier di Bandara Internasional Ngurah Rai, Bali. Dengan unit observasi sebanyak 250 responden yang terdiri dari beberapa kriteria responden. Metode penelitian adalah explanatory survey. Hasil pengujian menunjukkan total indirect effect paling tinggi adalah pengaruh service quality terhadap customer loyalty dengan nilai $t$ value sebesar 4,074 , selanjutnya service quality terhadap customer commitment dengan nilai $t$ value sebesar 3,243 di ikuti dengan sisa variabel lainnya. Hasil ini menunjukkan bahwa service quality merupakan variabel yang mendominasi pada hasil penelitian yang dilakukan. Semakin baik service quality yang diberikan maskapai kepada penumpang maka akan meninggkatkan komitmen penumpang dan selanjutnya akan menggiring penumapng untuk semakin loyal kepada maskapai.
\end{abstract}

Kata kunci : low cost carrier, service quality, customer satisfaction, brand trust, customer commitment, customer loyalty.

\section{PENDAHULUAN}

Transportasi pada dasarnya merupakan sarana yang digunakan untuk pemindahan manusia atau barang dari satu tempat ke tempat lainnya dengan menggunakan sebuah wahana yang digerakkan oleh manusia atau mesin. Transportasi digunakan untuk memudahkan aktivitas manusia. Secara umum, sarana transportasi terbagi menjadi tiga, transportasi darat, laut, dan udara. Masyarakat dapat menggunakan sarana atau alat transportasi sesuai dengan kebutuhan mereka. Salah satu alat transportasi yang dikenal dan sering digunakan oleh masyarakat luas terutama jika mereka mempertimbangkan efisiensi waktu adalah alat transportasi udara yaitu pesawat terbang.

Seiring perkembangan dunia usaha sekarang ini, pertumbuhan di bidang perekonomian baik jasa ataupun sektor industri berkembang dengan sangat pesat. Persaingan di bisnis penerbangan makin terfragmentasi karena hadirnya pemain-pemain swasta dengan permodalan yang cukup dan strategi penetrasi bisnis yang brilian. Khususnya munculnya pemain-pemain baru yang amat percaya diri dan cukup sukses mengambil positioning sebagai low cost carrier yaitu persaingan melalui rute penerbangan yang semakin mempermudah pelanggan untuk mencapai tujuan dengan biaya yang murah.

Terkait dengan harga dan pelayanan yang diberikan oleh maskapai penerbangan, terdapat fenomena yang mengemuka dan cukup menarik di tengah-tengah masyarakat. Untuk menarik banyak pelanggan untuk menggunakan maskapai penerbangannya, masingmasing perusahaan penerbangan menawarkan harga 
murah kepada masyarakat, terkadang harga tersebut jauh lebih murah dibanding penggunaan sarana transportasi lainnya tanpa disertai dengan fasilitas pelayanan yang maksimal khususnya pada saat penerbangan (Ruslan, 2013: 15). Pada sisi lain, masyarakat membutuhkan sarana tranportasi yang cepat dan murah tanpa mempertimbangkan hal-hal lain seperti faktor kenyamanan dan keselamatan. Maka dari itu maskapaimaskapai yang menawarkan harga murah tersebut selalu dicari dan menjadi rebutan para penumpang untuk mendapatkan tiket murah. Meskipun demikian, masih ada maskapai yang tetap mematok harga yang tinggi namun dengan tetap mempertahankan kualitas pelayanan yang prima, memberikan kenyamanan yang sesungguhnya bagi para penumpangnya dan tentu saja selalu memperhatikan keselamatan penumpang khususnya selama penerbangan (Neria, 2012: 52).

Terdapat beberapa tipe atau jenis penerbangan di Indonesia, yaitu penerbangan yang menerapkan sistem full service, yaitu maskapai penerbangan yang memberikan pelayanan secara maksimal terhadap kebutuhan konsumen, dimulai dari tersedianya makanan, snack, kapasitas bagasi yang lebih dan masih banyak lagi yang tentunya dengan harga yang sesuai (Kurniawan: 2012). Selain itu, terdapat maskapai yang menerapkan medium service system, maskapai penerbangan tersebut masih menyediakan snack dan kapasitas bagasi yang hampir sama dengan jenis full service yang tentunya dengan tarif yang lebih terjangkau oleh konsumen biasa. Selanjutnya ada pula yang menerapkan sistem low cost atau sering disebut penerbangan bertarif rendah, maskapai tersebut tidak menyediakan makanan ataupun snack tetapi menjual makanan di dalam pesawat tersebut dan juga mempunyai kapasitas bagasi yang sedikit lebih rendah dibandingkan dua sistem lainnya, seperti yang diterapkan oleh Lion Air Indonesia (Bambang,Budiyantono, 2014: 15).

Penerbangan bertarif rendah ini juga banyak diterapkan oleh maskapai-maskapai penerbangan lainnya, karena melihat situasi dan kondisi penumpang pada saat ini, yaitu ingin cepat sampai tujuan tetapi tidak memerlukan waktu yang lama. Jika dibandingkan dengan jasa yang lainnya, misalnya melalui darat ataupun laut, jalur udara merupakan alternatif yang paling baik digunakan karena selain dapat menghemat banyak waktu, juga dapat menghemat biaya. Dilihat dari market size, industri penerbangan cukup menggiurkan, Badan Pusat Statistik melansir jumlah penumpang angkutan udara periode Desember 2016, jumlah penumpang angkutan udara domestik mencapai 8 juta penumpang atau meningkat $16,98 \%$ dibanding November 2016. Sedangkan jumlah penumpang internasional naik $24,11 \%$ menjadi 1,5 juta penumpang.

Penumpang domestik sebanyak 80,4 juta orang atau naik 16,97 persen dan jumlah penumpang internasional sebanyak 14,8 juta orang atau naik 8,16 persen dibanding periode yang sama tahun 2015. Adapun jumlah penumpang angkutan udara internasional juga bertambah 2,95\% menjadi 1,1 juta orang dibandingkan pada September 2015 sebanyak 1,09 juta orang. Seperti yang ditujukkan oleh data statistik berikut ini:
Gambar. 1.1 Statistik Lalu Lintas Angkutan Udara Lalu Lintas Penumpang

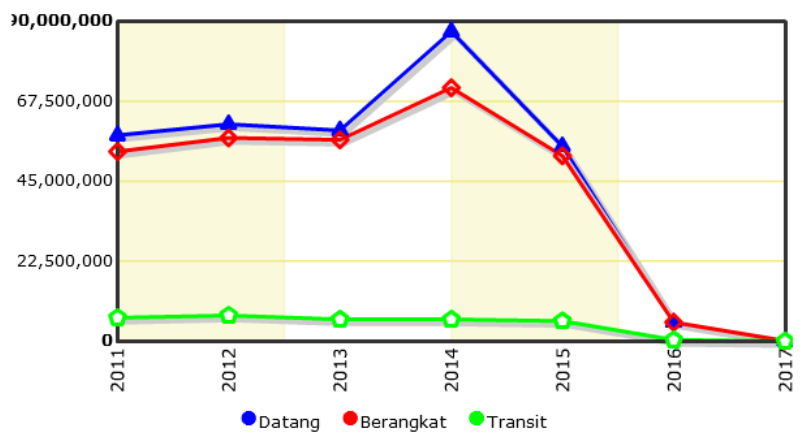

Kepuasan konsumen terhadap pelayanan yang diberikan oleh maskapai penerbangan di Indonesia sangat berpengaruh terhadap seberapa besar tingkat kualitas pelayanan dari sebuah maskapai penerbangan. Berbagai pelayanan yang mempengaruhi, kepuasan konsumen adalah keramahan seluruh awak kabin, fasilitas fisik yang ada, tarif penerbangan, ketepatan waktu keberangkatan kemudahan akses dan juga keselamatan penerbangan. Berdasarkan jajak pendapat dari 2.674 orang responden mengenai apa yang diinginkan dari sebuah maskapai penerbangan didapatkan hasil sebanyak 9,6\% menginginkan pelayanan ramah dari awak kabin, $16,9 \%$ penerbangan yang tepat waktu, armada yang baru 18,3\%, 55,2\% tarif yang murah (ongko.paulus widjojo, 2014).

Berdasarkan data di atas dapat diketahui berbagai hal antara lain ternyata konsumen masih belum puas terhadap keramahan dari para awak kabin di pesawat dan konsumen menginginkan waktu keberangkatan yang tepat waktu karena memang maskapai penerbangan di Indonesia sering mengalami keterlambatan waktu pada saat akan terbang atau dengan kata lain sering mengalami delay. Salah satu maskapai penerbangan di Indonesia yang sering mengalami keterlambatan dalam pemberangkatan pesawat adalah penerbangan low cost carriers. Ini merupakan On Time Performance (OTP) dari maskapai penerbangan low cost carrier di Indonesia hingga tahun 2015 .

Tabel. 1.2 On Time Performance untuk Maskapai LCC

\begin{tabular}{|c|c|c|c|c|c|}
\hline No & Maskapai & $\begin{array}{c}\text { Jumlah } \\
\text { Penerbangan }\end{array}$ & $\begin{array}{l}\text { Tepat } \\
\text { Waktu } \\
\text { (OTP) }\end{array}$ & $\begin{array}{c}\text { Keterlam } \\
\text { batan } \\
\text { (Delay) }\end{array}$ & $\begin{array}{l}\text { Pembatalan } \\
\text { (Cancel) }\end{array}$ \\
\hline 1 & Citilink & 30.598 & $\begin{array}{c}5.054 \\
(75,69 \%)\end{array}$ & $\begin{array}{c}1.577 \\
(23,62 \%)\end{array}$ & $\begin{array}{c}159 \\
(2,39 \%)\end{array}$ \\
\hline 2 & Lion Air & 86.043 & $\begin{array}{c}60.280 \\
(70,06 \%)\end{array}$ & $\begin{array}{c}25.403 \\
(29,52 \%)\end{array}$ & $\begin{array}{c}360 \\
(0,42 \%)\end{array}$ \\
\hline 3 & $\begin{array}{l}\text { Indonesia } \\
\text { Air Asia }\end{array}$ & 6.677 & $\begin{array}{c}5.054 \\
(75,69 \%)\end{array}$ & $323(17,60 \%)$ & $0(0 \%)$ \\
\hline
\end{tabular}

Sumber: Direktorat Jenderal Perhubungan Udara (2015)

\section{KAJIAN TEORITIK}

A. Deskripsi Konseptual

1. Jasa

2. Kualitas 
3. Kualitas Pelayanan

4. Dimensi Kualitas Pelayanan

5. Kepuasan Konsumen

6. Faktor Pembentukan Kepuasa Pelanggan

7. Pengaruh Kualitas Pelayanan Terhadap Kepuasan Konsumen

8. Merek (Brand)

9. Trust (Kepercayaan)

10. Kepercayaan Terhadap Merek (Trust In a Brand)

11. Komitmen

12. Komitmen Pelanggan

13. Loyalitas

14. Loyalitas Pelanggan

15. Loyalitas Merek (Brand Loyality)

Mahalnya biaya yang harus dikeluarkan perusahaan untuk menarik konsumen baru, maka perusahaan memprioritaskan untuk mempertahankan konsumen yang ada. Dalam menciptakan kepuasan dan loyalitas konsumen maka suatu perusahaan harus dapat memenuhi kebutuhan-kebutuhan konsumen yang dianggap paling penting disebut the big eight factor menurut Griffin (2015: 183) menyatakan secara umum loyalitas konsumen dapat tercipta dengan beberapa faktor, antara lain :

1. Faktor Produk

- Kualitas produk

- Hubungan nilai dengan harga

- Bentuk produk

- Keandalan

2. Faktor Pelayanan

- Jaminan

- Respon dan pemecahan masalah

3. Faktor Pembelian

- Pengalaman karyawan

- Kemudahan dan kenyamanan

Menurut Crasvens (2013: 191) menyatakan faktorfaktor yang mempengaruhi loyalitas konsumen adalah sebagai berikut:

- Performaproduk/jasa

- Citra perusahaan/produk/merek

- Hubungan harga dengan nilai

- Kinerja/prestasi karyawan

- Persaingan

- Sistem pengiriman produk tepat waktu

- Hubungan kepuasan dengan konsumen

Mengingat mahalnya biaya yang harus dikeluarkan perusahaan untuk menarik konsumen baru, maka perusahaan memprioritaskan untuk mempertahankan konsumen yang ada. Adapun cara yang dilakukan perusahaan dalam mempertahankan konsumen menurut Gaspersz (2015: 142) adalah:

- Andal (reable)

- Terpercaya (credible)

- Memikat (atractif)

- Bertanggung jawab (responsible)

\section{OBJEK DAN METODOLOGI PENELITIAN}

\section{A. Tujuan Penelitian}

a. Apakah service quality berpengaruh positif dan signifikan terhadap customer satisfaction pada pelanggan Maskapai Penerbangan low cost carrier di Bandara Internasional Ngurah Rai, Bali.

b. Apakah customer satisfaction berpengaruh positif dan signifikan terhadap brand trust pada pelanggan Maskapai Penerbangan low cost carrier di Bandara Internasional Ngurah Rai, Bali.

c. Apakah service quality berpengaruh positif dan signifikan terhadap customer commitment pada pelanggan Maskapai Penerbangan low cost carrier di Bandara Internasional Ngurah Rai, Bali.

d. Apakah customer satisfaction berpengaruh positif dan signifikan terhadap customer commitment pada pelanggan Maskapai Penerbangan low cost carrier Bandara Internasional Ngurah Rai, Bali.

e. Apakah brand trust berpengaruh positif dan signifikan terhadap customer commitment pada pelanggan Maskapai Penerbangan low cost carrier di Bandara Internasional Ngurah Rai, Bali.

f. Apakah customer commitment berpengaruh positif dan signifikan terhadap customer loyalty pada pelanggan Maskapai Penerbangan low cost carrier di Bandara Internasional Ngurah Rai, Bali.

g. Apakah customer satisfaction memediasi hubungan antara service quality dan brand trust pada pelanggan Maskapai Penerbangan low cost carrier di Bandara Internasional Ngurah Rai, Bali.

h. Apakah customer commitment memediasi hubungan antara service quality dan customer loyalty pada pelanggan Maskapai

i. Penerbangan low cost carrier di Bandara Internasional Ngurah Rai, Bali.

j. Apakah customer commitment memediasi hubungan antara brand trust dan customer loyalty pada pelanggan Maskapai Penerbangan low cost carrier di Bandara Internasional Ngurah Rai, Bali.

k. Apakah customer commitment memediasi hubungan antara service satisfaction dan customer loyalty pada pelanggan Maskapai Penerbangan low cost carrier di Bandara Internasional Ngurah Rai, Bali.

\section{B. Objek dan Ruang Lingkup penelitian}

Lokasi penelitian yang dilakukan, yaitu pada pelanggan maskapai penerbangan Low Cost Carrier yang berada di Bali, tempat ini dipilih karena aktivitas penerbangan yang tinggi yang stabil. Jenis penelitian adalah survey (self administered survey), definisi survei menurut Jogiyanto (2014: 115) adalah metode pengumpulan data primer dengan memberikan pertanyaan-pertanyaan kepada responden individu.

C. Waktu dan Tempat Penelitian

Penelitian ini akan dilakukan pada pengguna jasa penerbangan di wilayah Bali, dimana 
pelaksanaannya akan berlangsung selama dua bulan yaitu pada bulan Mei sampai dengan Juli 2017.

D. Metode penelitian

Penelitian ini dilakukan secara kuantitatif yang menggunakan conclusive research design dengan metode penelitian deskriptif serta kausal. Menurut Malhotra (2012: 73), desain penelitian konklusif adalah desain riset yang diciptakan untuk membantu peneliti dalam menentukan, mengevaluasi, dan memilih cara terbaik dalam menyikapi situasi yang ada. Metode penelitian deskriptif adalah suatu jenis riset konklusif yang mempunyai tujuan utama menguraikan sesuatu, biasanya karakteristik atau fungsi pasar.

Dalam penelitian ini, studi deskriptif dilakukan untuk mengetahui dan menjelaskan seberapa besar hubungan antara variabel kualitas pelayanan, kepuasan pelanggan, kepercayaan merek, terhadap komitmen pelanggan serta dampaknya pada loyalitas pelanggan pada maskapai penerbangan low cost carrier di Indonesia. Konstelasi penelitian ini seperti yang terlihat pada Gambar 3.1:

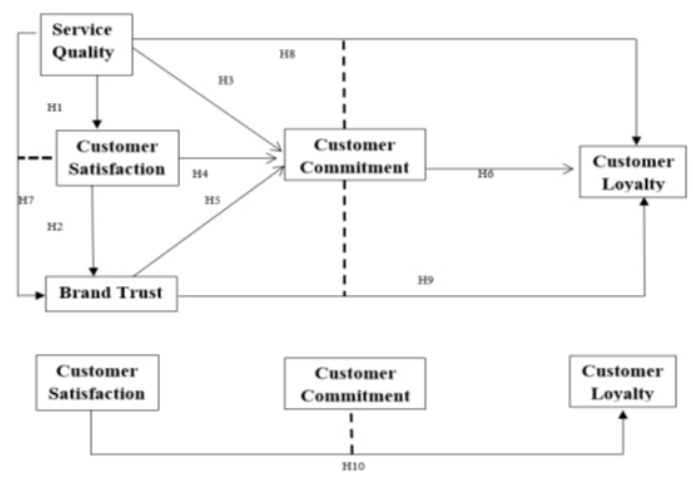

Gambar 3.1 Kerangka Model penelitian

E. Teknik Pengumpulan Data

Dalam usaha memperoleh data yang dibutuhkan, metode yang digunakan adalah:

- Studi Kepustakaan (Library Research)

- Penelitian Lapangan (Field Research)

F. Operasionalisasi Variabel

Variabel penelitian ini terdiri dari tiga jenis variabel, yaitu variable independen/bebas, variabel dependen/terikat dan variable mediator. Variabel merupakan suatu atribut atau sifat atau nilai dari orang, obyek atau kegiatan yang mempunyai variasi tertentu yang ditetapkan oleh peneliti untuk dipelajari dan ditarik kesimpulannya (Sugiyono, 2013: 59). Variabel penelitian dapat dibagi menjadi dua, yaitu:

- Variabel Independen/Bebas Konstruk Eksogen.

- Variabel Moderator.

- VariabelDependen/Terikat/Konstruk Endogen.

Agar penelitian ini dapat dilaksanakan sesuai dengan yang diharapkan,maka perlu dipahami berbagai unsur-unsur yang menjadi dasar dari suatu penelitian ilmiah yang termuat dalam operasionalisasi variabel penelitian. Secara lebih rinci, operasionalisasi variabel penelitian adalah sebagai berikut:
1. Kualitas Pelayanan

2. Kepuasan Pelanggan

3. Kepercayaan Merek

4. Komitmen Pelanggan

5. Loyalitas Pelanggan

G. Pengujian Validitas dan Perhitungan Reabilitas

1. Uji Validitas

Validitas instrumen adalah "untuk menunjukkan sejauhmana suatu alat mampu mengukur apa yang diukur". Validitas adalah kesahihan. Validitas menunjuk pada sejauh mana suatu alat mampu mengukur apa yang seharusnya diukur. Pengukuran ini dilakukan dengan menggunakan teknik metode korelasi dari Pearson. Teknik ini digunakan untuk menguji apakah tiap item pertanyaan mampu mengungkapkan faktor yang akan diukur atau konsistensi internal tiap item alat ukur dalam mengukur suatu faktor.

Validitas dalam penelitian ini adalah validitas item kuesioner. Validitas item digunakan untuk mengukur ketepatan atau kecermatan suatu item suatu item dalam mengukur apa yang ingin diukur. Item yang valid ditunjukkan dengan adanya korelasi antara item dan skor total item. Rumus yang digunakan dalam uji validitas dengan menggunakan rumus Pearson Product Moment:

$$
r=\frac{\left|N \cdot \Sigma X_{i} X_{t}\right|-\Sigma X_{i}\left|\Sigma X_{t}\right|}{\sqrt{\mid N \cdot \Sigma X_{i}^{2}-\left(\left.\Sigma X_{i}\right|^{2}|| N \cdot \Sigma X_{t}^{2}-\left.\Sigma X_{t}\right|^{2}\right.}}
$$

Keterangan:

$\begin{array}{ll}\mathrm{rXY} & =\text { Koefisien Korelasi } \\ \mathrm{N} & =\text { Jumlah Responden } \\ \mathrm{X} & =\text { Skor Butir } \\ \mathrm{Y} & =\text { Skor total }\end{array}$

Dalam penentuan apakah suatu item layak digunakan atau tidak yaitu dengan cara uji signifikansi koefesien korelasi pada taraf signifikansi 0,05. Yang artinya adalah suatu item dianggap valid jika berkorelasi signifikan terhadap skor total item.Keputusan untuk uji validitas sebagai berikut:

Jika $\mathbf{r}$ hitung $>$ r tabel, maka

dikatakan valid

Jika $\mathbf{r}$ hitung $<\mathbf{r}$ tabel, maka dikatan tidak valid

Berdasarkan hasil uji validitas dengan menggunakan rumus korelasi Pearson Product Moment pada variabel akan didapatkan nilai koefisien korelasi pada masing-masing item pertanyaan adalah $>\mathrm{r}$ tabel $(0,361)$. Hal ini yang akan membuktikan bahwa item pertanyaan yang digunakan valid jika koefisien korelasi diatas 0,361 dari seluruh item 
pertanyaan terdapat 2 item yang tidak valid karena koefisien korelasi di bawah 0,361.

2. Perhitungan Reabilitas

Reliabilitas adalah suatu alat pengukur, yang menunjukan bahwa suatu instrumen cukup dapat dipercaya untuk digunakan sebagai alat pengumpul data karena instrumen sudah baik. Suatu variabel dinyatakan reliabel, jika nilai Alpha Cronbach's lebih besar atau sama dengan 0,600, sedangkan bila nilai Alpha Cronbach's lebih kecil 0,600, variabel tersebut dapat dikatakan tidak reliabel. Adapun rumus Alpha Cronbach's sebagai berikut:

$$
r_{11}=\frac{k}{k-1}\left(1-\frac{\sum s i^{2}}{s t^{2}}\right)
$$

Keterangan:

Dimana:

rit $=$ Koefisien reliabilitas instrumen

$\mathrm{k}=$ jumlah butir instrumen yang valid

$\mathrm{Si}^{2}=$ varians butir

$\mathrm{St}^{2}=$ varians total

Jadi, alat ukur dapat reliabel jika nilai reliabilitasnya $>0,600$.

Cronbach's Alpha $<\mathbf{0 , 6}=$ reliabilitas buruk

Cronbach's Alpha $\mathbf{0 , 6}-\mathbf{0 , 7 9}=$ reliabilitas diterima

Cronbach's Alpha $>\mathbf{0 , 8}=$ reliabilitas baik

Berdasarkan perhitungan uji reliabilitas, maka akan terdapat hasil yang akan menunjukkan reliabilitas dari variabel-variabel penelitian dengan menggunakan Alpha Cronbach's.

H. Pengujian Validitas dan Perhitungan Reabilitas

1. Merancang Metode Pengukuran

2. Merancang modul Struktur (Inner Model)

3. Konstruksi Diagram Jalur

4. Konversi Diagram Jalur ke Sistem Persamaan

5. Evaluasi Goodness Of Fit

6. Hipotesis Statistika (Resampling Bootstraping

\section{HASIL PENELITIAN DAN PEMBAHASAN}

\section{A. Hasil Penelitian}

Pada bab ini akan dijabarkan hasil penelitian mengenai pengaruh service quality, customer satisfaction dan brand trust terhadap customer commitment serta dampaknya terhadap customer loyalty pada pelanggan maskapai penerbangan low cost carrier di Indonesia. Data yang digunakan dalam penelitiian ini adalah data primer dengan menggunakan kuesioner sebagai alat pengumpulan data. Dalam kuesioner tersebut terdapat 5 variabel dengan jumlah pernyataan sesuai dengan jumlah indicator Sebagai berikut :

1. Service quality sebanyak 12 pernyataan
2. Customer satisfaction sebanyak 4 pernyataan

3. Brand trust sebanyak 4 pernyataan

4. Customer commitment sebanyak 4 pernyataan

5. Customer loyalty sebanyak 9 pernyataan

Kuesioner yang telah disebarkan sebanyak 250 kuesioner kepada 250 orang pelanggan maskapai penerbangan domestik di bandara internasional I Gusti Ngurah Rai, Bali, selama periode bulan Mei sampai dengan Juli 2017. Dengan tingkat pengembalian kuesioner sebanyak 100\% sehingga semua kuesioner tersebut bias digunakan sebagai sumber data pada penelitian ini. Tinkat pengembalian kuesioner senanyak $100 \%$ dapat diartikan bahwa kuesioner bisa diterima dengan baik dan hasil jawaban kuesioner dapat diolah,karna response rate lebih besar dari pada acceptable yaitu sebesar 60-69\% (Subagio Hartono. 2012)

B. Langkah-langkah Analisis Persamaan Partial least Square(PLS)

Analisis ini dilakukan berdasarkan tujuan penelitian, adapun langkah-langkahnya sebagai berikut:

1. Hubungan Antar Variabel

Dalam penelitian ini, model struktural yang dianalisis memenuhi model reflektif dengan semua indikator dari tiga variabel eksogen yakni: service quality (X1) dan customer satisfaction(X2), brand trust(X3) Konstruk formatif mengasumsikan bahwa indikator mempengaruhi konstruk/variabel laten (arah hubungan kausalitas dari indikator ke konstruk). Dalam penelitian ini, model struktural yang dianalisis memenuhi model formatif dengan semua indikator dari variabel endogen yakni; customer commitment (Y) dan customer loyalty (Z).

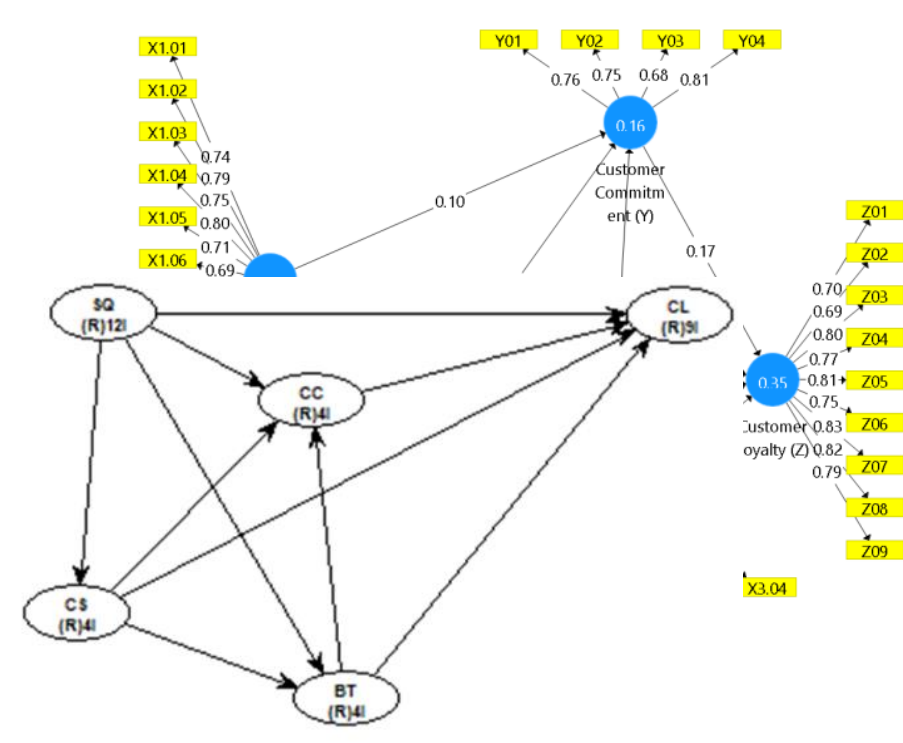

2. Diagran Jalur(Diagram Path) PLSBerdasarkan kerangka konseptual penelitian yang dibangun atas dasar teori 
dan konsep, maka dapat digambarkan model empirik penelitian seperti Gambar

4.1.

Gambar 4.1 Diagram alur

Keterangan:

$S Q$ : Service Quality

CS : Customer Satisfaction

BT : Brand Trust

$C C$ : Customer Commitment

CL : Customer Loyalty

3. Evaluasi Model PLS

Evaluasi model struktural digunakan untuk menguji ada atau tidaknya pengaruh antar konstruk dan $R$ Square. Model structural dievaluasi dengan menggunakan $P$ value dengan maksud untuk mengetahui nilai signifikansi dari koefisien parameter jalur structural dan $R$ Square sehingga dapat diketahui pengaruh variable laten independen terhadap variable laten dependen yang mungkin memiliki pengaruh substantive.

Dalam menilai model struktural dengan struktural PLS dapat dilihat dari nilai $R$ Squares untuk setiap variabel laten endogen sebagai kekuatan prediksi dari model struktural. Nilai $R$-Squares merupakan uji goodness fit model. Perubahan nilai $R$ Squares digunakan untuk menjelaskan pengaruh variabel laten eksogen tertentu terhadap variabel laten endogen, apakah mempunyai pengaruh substantive.

Gambar 4.2. Hasil permodelan

\section{KESIMPULAN}

Berdasarkan hasil analisis menggunakan software SmartPLS dan pembahasan mengenai pengaruh service quality, customer satisfaction, brand trust terhadap customer commitment serta dampaknya kepada customer loyalty penumpang penerbangan domestic - low cost carrier di Bandara Internasional Ngurah Rai, Bali. Maka diperoleh kesimpulan sebagai berikut :

1. Hasil pengujian Hipotesisi 1, service quality berpengaruh secara signifikan berpengaruh terhadap customer satisfaction. Sehingga dapat disimpulkan bahwa semakin baik service quality yang diterima oleh penumpang maka akan dapat meningkatkan tingkat kepusan atau customer satisfaction pada penumpang. Maka H1 diterima.

2. Hasil pengujian Hipotesisi 2, customer satisfaction secara signifikan berpengaruh terhadap brand trust. Sehingga dapat disimpulkan bahwa semakin baik customer satisfaction yang dirasakan oleh penumpang maka akan dapat meningkatkan tingkat kepercayaan penumpang (brand trust) terhadap maskapai penerbangan tersebut. Maka H2 diterima.

3. Hasil pengujian Hipotesisi 3, service quality secara tidak signifikan berpengaruh terhadap customer commitment. Sehingga dapat disimpulkan bahwa service quality yang diterima oleh penumpang tidak mempengaruhi meningkatkan tingkat komitmen penumpang (customer commitment) terhadap maskapai penerbangan tersebut. Maka H3 ditolak.

4. Hasil pengujian Hipotesisi 4, customer satisfaction secara signifikan berpengaruh terhadap customer commitment. Sehingga dapat disimpulkan bahwa semakin baik customer satisfaction yang dirasakan oleh penumpang maka akan dapat meningkatkan tingkat komitment penumpang (customer commitment) terhadap maskapai penerbangan tersebut. Maka H4 diterima.

5. Hasil pengujian Hipotesisi 5, brand trust secara signifikan berpengaruh terhadap customer commitment. Sehingga dapat disimpulkan bahwa semakin baik kepercayaan penumpang (brand trust) maka akan dapat meningkatkan tingkat komitmen penumpang terhadap maskapai penerbangan tersebut. Maka H5 diterima.

6. Hasil pengujian Hipotesisi 6, customer commitment secara signifikan berpengaruh terhadap customer loyalty. Sehingga dapat disimpulkan bahwa semakin baik komitmen penumpang (customer commitment) maka akan dapat meningkatkan tingkat loyalitas penumpang terhadap maskapai penerbangan tersebut. Maka H6 diterima.

7. Hasil pengujian Hipotesisi 7, service quality secara tidak signifikan berpengaruh terhadap brand trust. Sehingga dapat disimpulkan bahwa service quality yang diterima oleh penumpang tidak mempengaruhi meningkatkan tingkat kepercayaan penumpang (brand trust) terhadap maskapai penerbangan tersebut. Maka H7 ditolak.

8. Hasil pengujian Hipotesisi 8, service quality secara signifikan berpengaruh terhadap customer loyalty. Sehingga dapat disimpulkan bahwa semakin baik service quality yang di terima penumpang maka akan dapat meningkatkan tingkat loyalitas penumpang terhadap maskapai penerbangan tersebut. Maka H8 diterima. 
9. Hasil pengujian Hipotesisi 9, brand trust secara signifikan berpengaruh terhadap customer loyalty. Sehingga dapat disimpulkan bahwa semakin baik kepercayaan penumpang (brand trust) maka akan dapat meningkatkan tingkat loyalitas penumpang (customer loyalty) terhadap maskapai penerbangan tersebut. Maka H9 diterima.

10. Hasil pengujian Hipotesisi 10, customer satisfaction secara tidak signifikan berpengaruh terhadap customer loyalty. Sehingga dapat disimpulkan bahwa customer satisfaction yang dirasakan oleh penumpang tidak meningkatkan tingkat loyalitas penumpang (customer loyalty) terhadap maskapai penerbangan tersebut. Maka H10 diterima.

\section{DAFTAR PUSTAKA}

Akbar, Febrian, (2014). Kurnia. Pengaruh Komitmen Organisasional, Komitmen Profesional, Motivasi Kerja dan Konflik Peran Terhadap Kepuasan Kerja Auditor (Studi Empiris pada Kantor Akuntan Publik di DKI Jakarta). Jakarta: Skripsi Uin Syarif Hidayatullah Jakarta.

Bambang Budiyantono, (2014).Pengaruh Kualitas Pelayanan dan Produk yang Ditawarkan terhadap Kepuasan Anggota Koperasi Karyawan Widyagama Malang

Griffin, R.W.(2015). Management, Edisi 7, Jilid 1, Jakarta: Penerbit Erlangga.

Gaspersz, V. (2015). Practical Management Excellence, Bogor : Vinchristo Publication

H.M., Jogiyanto. (2014), Metodologi Penelitian bisnis: salah kaprah dan pengalaman-pengalaman. Yogyakarta: Penerbit BPFE.

Kurniawan, Wahyu,(2012).Analisis Pengaruh Kualitas Pelayanan,Kualitas Produk dan Harga Terhadap Kepercayaan Konsumen Produk Notebook (Studi Kasus Terhadap Dua Merk Notebook),Program studi Manajemen Fakultas Ekonomi Universitas Muhammadiyah Surakarta

Malhotra, N. (2012). Riset Penelitian: Pendekatan Terapan(Ed.8).Jakarta: PT. Indeks Kelompok Gramedia.

Neria, M. (2012). Pengaruh citra merek terhadap loyalitas konsumen maskapai penerbangan garuda indonesia. Jakarta: Universitas Indonesia

Ongko, Paulus Widjojo, (2014).Pengaruh Persepsi Nilai Pelanggan dan Kepuasan Konsumen Terhadap Loyalitas Konsumen Hypermart Pakuwon Trade Center di Surabaya, Jurusan Manajemen Fakultas Bisnis universitas Katolik Widya Manggala Surabaya

Ruslan, Rosady. (2013). Manajemen Public Relations dan Media Komunikasi.Jakarta :Rajawali Pers.

Sugiyono, (2013). Metode penelitian bisnis. Penerbit Alfabeta, Bandung

Subagio Hartono, Saputra Robin. (2012). Pengaruh Perceived Service Quality,Perceived Value, Satisfaction dan Image Terhadap Customer Loyalty(Studi Kasus Garuda Indonesia), Jurnal Manajemen Pemasaran,7(5): h:42-52. 
